This item was submitted to Loughborough's Research Repository by the author.

Items in Figshare are protected by copyright, with all rights reserved, unless otherwise indicated.

\title{
An experiment to assess the effects of diatom dissolution on oxygen isotope ratios
}

PLEASE CITE THE PUBLISHED VERSION

http://dx.doi.org/10.1002/rcm.7446

\section{PUBLISHER}

(C) John Wiley \& Sons

\section{VERSION}

AM (Accepted Manuscript)

\section{PUBLISHER STATEMENT}

This work is made available according to the conditions of the Creative Commons Attribution-NonCommercialNoDerivatives 4.0 International (CC BY-NC-ND 4.0) licence. Full details of this licence are available at: https://creativecommons.org/licenses/by-nc-nd/4.0/

\section{LICENCE}

CC BY-NC-ND 4.0

\section{REPOSITORY RECORD}

Smith, Andrew C., Melanie J. Leng, George E.A. Swann, Philip A. Barker, Anson W. Mackay, David Ryves, Hilary J. Sloane, Simon R.N. Chenery, and Michael Hems. 2019. "An Experiment to Assess the Effects of Diatom Dissolution on Oxygen Isotope Ratios". figshare. https://hdl.handle.net/2134/21624. 


\section{An experiment to assess the effects of diatom dissolution on oxygen isotope ratios}

Andrew C. Smith ${ }^{\mathrm{a}^{*}}$, Melanie J. Leng ${ }^{\mathrm{a}, \mathrm{b}}$, George E.A. Swann ${ }^{\mathrm{b}, \mathrm{c}}$, Philip A. Barker ${ }^{\mathrm{d}}$, Anson W. Mackay ${ }^{\mathrm{e}}$, David B. Ryves ${ }^{\mathrm{f}}$, Hilary J. Sloane ${ }^{\mathrm{a}}$, Simon R.N. Chenery ${ }^{\mathrm{g}}$, Mike Hems ${ }^{\mathrm{h}}$

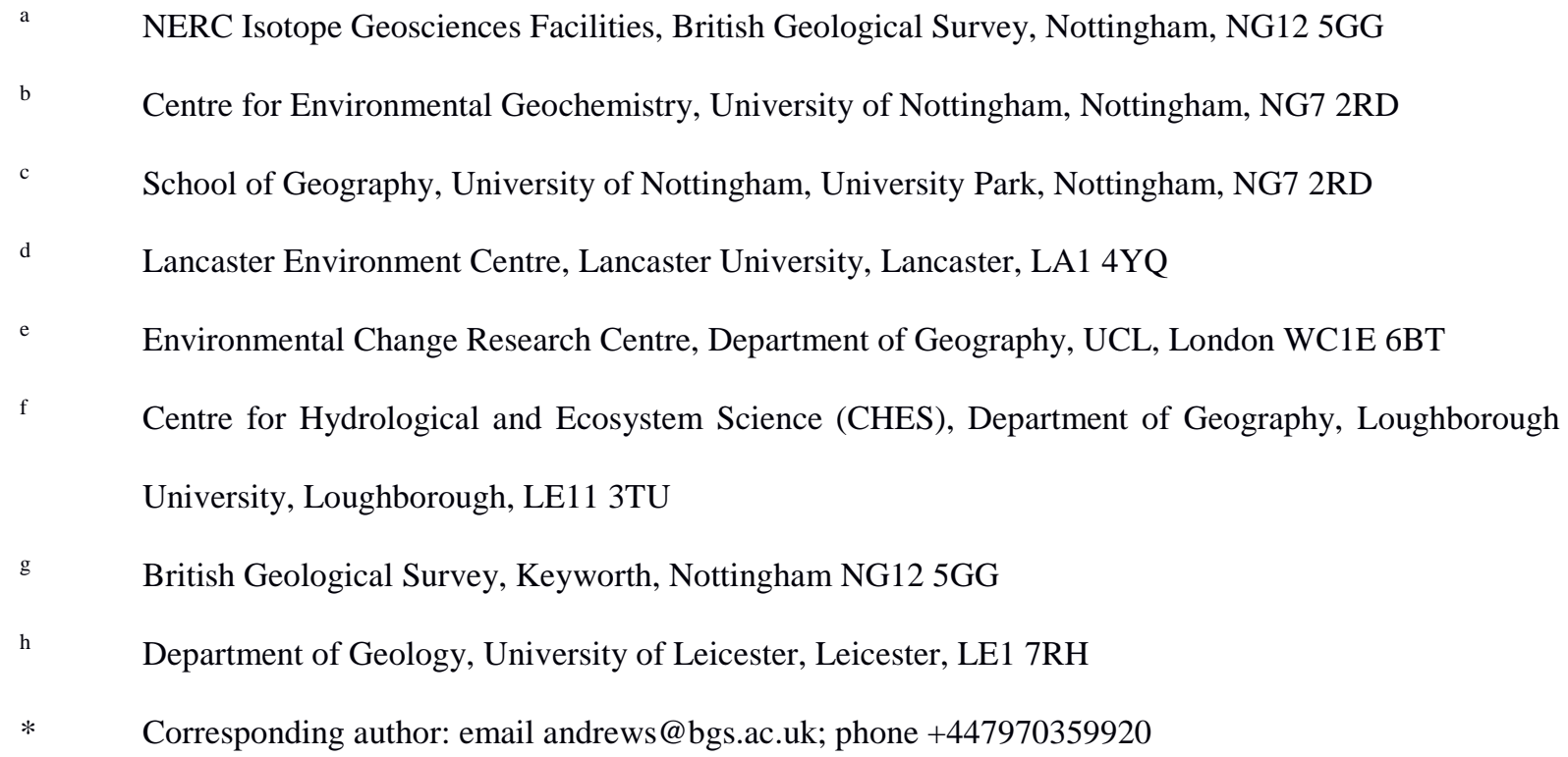

\section{Abstract}

Rational: Current studies which use the oxygen isotope composition from diatom silica $\left(\delta^{18} \mathrm{O}_{\text {diatom }}\right)$ as a palaeoclimate proxy assume that $\delta^{18} \mathrm{O}_{\text {diatom }}$ reflects the isotopic composition of the water in which the diatom formed. However, diatoms dissolve post mortem, preferentially losing less silicified structures in the water column and during/after burial into sediments. The impact of dissolution on $\delta^{18} \mathrm{O}_{\text {diatom }}$ and potential misinterpretation of the palaeoclimate record is evaluated.

Methods: Diatom frustules covering a range of ages (6 samples from the Miocene to the Holocene), environments and species were exposed to a weak alkaline solution for 48 days at two temperatures $\left(20^{\circ} \mathrm{C}\right.$ and $\left.4^{\circ} \mathrm{C}\right)$, mimicking natural dissolution post mucilage removal. Following treatment, dissolution was assessed using Scanning Electron Microscope images and a qualitative diatom dissolution index. Diatoms were subsequently analysed for $\delta^{18} \mathrm{O}$ using Step Wise Fluorination and Isotope Ratio Mass Spectrometry. 
Results: Variable levels of diatom dissolution were observed between the 6 samples, in all cases higher temperatures resulted in more frustule degradation. Dissolution was most evident in younger samples, likely as a result of the more porous nature of the silica. The degree of diatom dissolution does not directly equate to changes in isotope value; $\delta^{18} \mathrm{O}_{\text {diatom }}$ was however lower after dissolution, but in only half the samples was this reduction outside the analytical error $(2 \sigma$ analytical error $=0.46 \%)$.

Conclusions: We show that dissolution can have a small negative impact on $\delta^{18} \mathrm{O}_{\text {diatom }}$ causing reductions of up to $0.59 \%$ o beyond analytical error $(0.46 \%$ ) at natural environmental temperatures. These findings need to be considered in palaeoenvironmental reconstructions

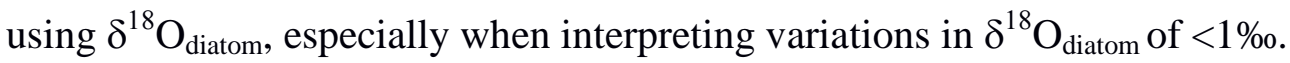

\section{Keywords: Palaeoclimate, biogenic silica, oxygen isotopes, dissolution, sedimentation}

\section{Introduction}

Use of the oxygen isotope composition of biogenic silica (most often diatom silica; $\delta^{18} \mathrm{O}_{\text {diatom }}$ ) in palaeoclimate reconstructions from both lake and ocean studies is increasing. ${ }^{[1,2]}$ Diatom $\delta^{18} \mathrm{O}$ offers an alternative to more traditional carbonate $\delta^{18} \mathrm{O}$ analysis, especially in environments where carbonates are not well preserved. For example, Pike et al., (2013) ${ }^{[3]}$ used $\delta^{18} \mathrm{O}_{\text {diatom }}$ to reconstruct the amount of melting along the Antarctic Peninsula through the Holocene, and Mackay et al., (2013) ${ }^{[4]}$ use $\delta^{18} \mathrm{O}_{\text {diatom }}$ from Lake Baikal to understand the extent of Northern Hemisphere climate forcing over central Asia during the Last Interglacial. These studies assume that the $\delta^{18} \mathrm{O}_{\text {diatom }}$ is fixed in the frustules during formation and that the signal is not subsequently altered post mortem by interactions with isotopically different fluids, or by dissolution, either during sinking or in the sediments. This assumption, however, is inconsistent with kinetic theory, as equilibrium is dynamic, and mass transfer continues at the mineral-fluid interface even after the diatom frustule attains equilibrium with the bulk fluid. This is especially pertinent to biogenic silica because of its hydrous nature $\left(\mathrm{SiO}_{2} \cdot \mathrm{nH}_{2} \mathrm{O}\right){ }^{[5,6]}$

The aim of the experiments reported here was to assess the impact of post mortem biogenic silica dissolution and potentially re-equilibration on sedimentary diatom $\delta^{18} \mathrm{O}$, similar to investigations into the effect of dissolution on silicon isotopes in diatoms. ${ }^{[7]}$ Diatoms often partially (or fully) dissolve post mortem during sinking and burial within the sediment record, 
causing the component of the frustule that remains to be only partially representative of the original. ${ }^{[8]}$ We questioned if the isotope composition of the frustule may change through dissolution due to removal of the most easily dissolved components in diatoms of different age. One laboratory dissolution experiment (at pH 9 using $\mathrm{NaOH}$ ) carried out by Moschen et al., (2006) $)^{[9]}$ on modern diatoms observed isotope deviations of up to $6.9 \%$ due to dissolution, following the removal of the protective organic matter coating around the cultured frustule, whereas Dodd et al. (2012) ${ }^{[6]}$ report a 7\%o shift from living to sedimentary diatoms, related to silicate maturation. To test more fully if such extreme fractionation may occur due to post burial dissolution (assessed by a visual dissolution index; c.f. Ryves et al., $2006^{[10]}$ ), we carried out further experiments. We mimicked dissolution in the laboratory on a suite of monospecific and mixed diatom assemblage of different ages, from both marine and lacustrine environments, and dissolved them to different degrees over varying time and at two temperatures.

\section{Previous Studies}

Diatom dissolution experiments have previously been undertaken to assess structural changes in community composition ${ }^{[11,12,13]}$ and alteration of oxygen and silicon isotope ratios $^{[7,9]}$ using a variety of reagents. These studies demonstrate that the removal of organic components and metal ions greatly accelerates dissolution through contact between the solution and the silica structure. ${ }^{[9]}$ Even after the removal of the organic coating, Ryves et al., $(2001)^{[13]}$ found that partial dissolution took several weeks when conducted in distilled water at $25^{\circ} \mathrm{C}$ buffered to $\mathrm{pH}$ 10. Dissolution rates are affected by several factors, including the silica concentration of the solution, $\mathrm{pH}$ and temperature of the solution ${ }^{[13]}$ as well as the amount of diatom silica remaining and the proportion of this silica which is resistant to dissolution. ${ }^{[9]}$ In natural sediments pore water chemistry is more important than ambient lake water conditions and dissolution is often greater in more open sediment structures. However, Flower \& Ryves (2009) ${ }^{[14]}$ found that preservation is better (i.e. less dissolution) at higher sediment accumulation rates and suggested this was due to rapid burial and build-up of silica saturation levels in pore water.

Bulk dissolution rate in sediments is therefore not linear but decreases over time, ${ }^{[7,15]}$ both as pore water concentrations rise to saturation but also as the assemblage specific surface area is reduced, slowing dissolution. ${ }^{[7]}$ Within sediments, dissolution is greatest at the point of burial 
while the rate decreases in older sediments as a result of greater crystallinity in older diatoms. ${ }^{[16]}$ At the scale of individual valves specific surface area is also important to dissolution rates, as valves dissolve their surface area to volume ratio changes altering the rate of dissolution. ${ }^{[12,13]}$ Finally, the ultra-structure of the diatom frustule can also have significant effects on the rate of dissolution as susceptibility to dissolution is not uniform across the valve. Within the silica ultra-structure of the valve, a variety of bond geometries exist. Specifically the arrangement of silica and oxygen atoms may be denoted by $\mathrm{Q}_{\mathrm{n}}$, where $\mathrm{n}$ denotes the number of silicon atoms connected to four bridging oxygen atoms. ${ }^{[17]}$ For example $\mathrm{Q}_{4}$ denotes a silicon atom joined to four other silicon atoms via four bridging oxygen atoms (i.e. $\left.\mathrm{Si}(\mathrm{OSi})_{4}\right), \mathrm{Q}_{3}$ therefore denotes a silicon atom connected to three other silicon atoms via three bridging oxygen atoms, with the fourth oxygen forming a hydroxyl group (i.e. ( $\mathrm{SiO}) \mathrm{Si}-\mathrm{OH}$ ). The majority of bonds present are typically either $\mathrm{Q}_{4}$ or $\mathrm{Q}_{3}$, leading to the ratio $\mathrm{Q}_{4} / \mathrm{Q}_{3}$ being quoted to indicate the hydration level. ${ }^{[17]}$ Importantly, a higher $\mathrm{Q}_{4} / \mathrm{Q}_{3}$ ratio gives a silica structure more resistance to dissolution, owing to the lower bond energy of the hydroxyl groups compared to the Si-O-Si bonds. ${ }^{[18]}$

Previous studies have tried to explain post mortem $\delta^{18} \mathrm{O}_{\text {diatom }}$ variation, looking specifically at the effects of dissolution. ${ }^{[9,19]}$ The study of Moschen et al., (2006) ${ }^{[9]}$ involved sediment traps in Lake Holzmaar, Germany, to investigate changes in $\delta^{18} \mathrm{O}_{\text {diatom }}$ during settling at different water depths $(0-7 \mathrm{~m}$ and $20 \mathrm{~m})$. Their results show an increase in $\delta^{18} \mathrm{O}_{\text {diatom }}$ with depth, associated primarily with the re-suspension of older diatoms which had undergone significant levels of silicate maturation. Importantly, subsequent laboratory experiments conducted using buffered (pH 5.6 and $\mathrm{pH}$ 9) solutions and both cultured and natural diatoms (untreated, and cleaned of organic coatings using $\mathrm{H}_{2} \mathrm{O}_{2}$ ) found a $\delta^{18} \mathrm{O}_{\text {diatom }}$ increase of up to $+6.9 \%$ after two days at $\mathrm{pH} 9,{ }^{[9]}$ although no change was found in $\delta^{18} \mathrm{O}_{\text {diatom }}$ in the lower $\mathrm{pH}$ solution. In the untreated samples, where the organic mucilage was retained, they found limited dissolution of biogenic silica and no oxygen isotope change. ${ }^{[9]}$ The natural diatom assemblage underwent very little dissolution in comparison to the cultured diatoms, the "older" natural diatoms being more resilient to both dissolution and $\delta^{18} \mathrm{O}_{\text {diatom }}$ change. ${ }^{[9,19]}$ These results highlight the potential importance of dissolution in controlling $\delta^{18} \mathrm{O}_{\text {diatom }}$ in diatom assemblages of different ages.

\section{Materials and Methods}


Six samples were selected (most of which had been previously analysed for $\delta^{18} \mathrm{O}_{\text {diatom, Table }}$ 1) that cover a range of sedimentary environments and species composition. From oldest to youngest, these were: 1) Burney California Diatomite (BFC) (Miocene lacustrine deposit), 2) North West Pacific Ocean (Pliocene marine deposit), 3) Bering Sea (Pliocene marine deposit), 4) Gil-Gil Kenya Diatomite (KFC) (Pleistocene lacustrine deposit), 5) Lake Baikal (Pleistocene lacustrine deposit), 6) Lake Challa (Pleistocene lacustrine deposit). All these samples would have undergone an unknown amount of prior dissolution during settling and burial. The samples had been previously cleaned and prepared for isotope analysis which removed any carbonate or siliclastic particles but also removed any remaining organic components (see original publications in Table 1). The six samples were sieved and cleaned of silt material until they contained over 90\% diatom silica (visually assessed using either a Scanning Electron Microscope and/or a light microscope), with the exception of KFC which contained a significant proportion of clay which could not be removed during processing, and the Bering Sea sample, which contained up to $15 \%$ sponge spicules which were similar in size and density to the diatoms (see original publications in Table 1).

\begin{tabular}{|c|c|c|c|c|c|}
\hline Name & Origin & Age & Description & Taxa & $\begin{array}{l}\text { Reference /Supplied } \\
\text { by }\end{array}$ \\
\hline BFC & $\begin{array}{l}\text { Shastra County, } \\
\text { California, USA }\end{array}$ & Miocene & $\begin{array}{l}\text { Lacustrine deposit } \\
\text { Laboratory standard }\end{array}$ & $\begin{array}{l}\text { Aulacoseira spp. } \\
\text { Stephanodiscus spp. }\end{array}$ & $\begin{array}{l}\text { Chapligin et al (2011) } \\
\text { Leng and Slone } \\
\text { (2008)/ NIGL* }\end{array}$ \\
\hline $\begin{array}{l}\text { North West } \\
\text { Pacific }\end{array}$ & $\begin{array}{l}\text { ODP site } 882 \\
\text { GS24-29 }\end{array}$ & $\begin{array}{l}\text { Pliocene } \\
\text { (2.8 Ma) }\end{array}$ & Marine deposit & Coscinodiscus radiatus & Swann et al (2006) \\
\hline Bering Sea & Site U1340 & $\begin{array}{l}\text { Pliocene } \\
\text { (2.6-3.6 Ma) }\end{array}$ & Marine deposit & Coscinodiscus marginatus & G.Swann \\
\hline KFC & Gilgil, Kenya & Pleistocene & $\begin{array}{l}\text { Lacustrine deposit } \\
\text { Laboratory standard }\end{array}$ & $\begin{array}{l}\text { Aulacoseira spp. } \\
\text { Stephanodiscus spp. }\end{array}$ & $\begin{array}{l}\text { Tyler et al (2006)/ } \\
\text { NIGL* }\end{array}$ \\
\hline Lake Baikal & $\begin{array}{l}\text { Lake Baikal, } \\
\text { Russia }\end{array}$ & $\begin{array}{l}\text { Pleistocene } \\
(120-127 \\
\text { ka) }\end{array}$ & Lacustrine deposit & $\begin{array}{l}\text { Aulacoseira skvortzowii } \\
\text { Stephanodiscus grandis } \\
\text { Stephinodiscus formosusvar } \\
\text { minor }\end{array}$ & $\begin{array}{l}\text { Mackay et al (2013) } \\
\text { Rioual and Mackay } \\
\text { (2005) }\end{array}$ \\
\hline Lake Challa & $\begin{array}{l}\text { Lake Challa, E. } \\
\text { Africa }\end{array}$ & $\begin{array}{l}\text { Pleistocene } \\
\text { (12-25 ka) }\end{array}$ & Lacustrine deposit & $\begin{array}{l}\text { Gomphocymbella spp. } \\
\text { Nitzschia spp. }\end{array}$ & Barker et al (2013) \\
\hline
\end{tabular}

* NERC Isotope Geosciences Facilities

Table 1: List of samples used in the dissolution experiments; highlighting prominent assemblage taxa and sample supplier. 
The six samples were either near-monospecific or mixed diatom assemblages, the dominant species composition for each sample is summarised in Table 1. Prior to dissolution experiments, a subsample of each was analysed for $\delta^{18} \mathrm{O}$. Further subsamples (25 mg) were placed in a $5 \% \mathrm{NaCO}_{3}$ solution $\left(250 \mathrm{ml}\right.$, made up with deionised water, $\delta^{18} \mathrm{O}=-7 \%$ o, $\mathrm{pH}$ c. 11.5) to ensure silica did not become oversaturated during the experiment and to mimic natural dissolution post mucilage removal. ${ }^{[20]}$ Dissolution was allowed to proceed for 48 days at two temperatures $\left(20^{\circ} \mathrm{C}\right.$ and $\left.4^{\circ} \mathrm{C}\right)$ representing a range of temperatures including low temperatures found within bottom waters (and therefore sediments) of high latitude lakes and the oceans. The samples were kept in beakers with para film coverings to prevent evaporation and the samples were not stirred; the $20^{\circ} \mathrm{C}$ experiment was conducted in a fume cupboard and the $4^{\circ} \mathrm{C}$ in a fridge. A control subsample was taken from three of the diatom assemblages (BFC, North West Pacific and Bering Sea) and placed in de-ionised (DI) water for the 48 day period ( $\mathrm{pH}$ c.7, $20^{\circ} \mathrm{C}$ ). The reactions were halted by filtering onto cellulose nitrate filters $(3 \mu \mathrm{m})$, washing in deionised water and drying at $40^{\circ} \mathrm{C}$. To ensure that changes in $\delta^{18} \mathrm{O}_{\text {diatom }}$ are not related to different rates of dissolution between species, qualitative assessment of diatom composition before and after dissolution was assessed using both light (LM) and scanning electron microscopes (SEM) and only minor changes in assemblage composition were identified, potentially related to heterogeneity across the viewing surface of the slide. For SEM imaging, samples were mounted on carbon tipped aluminium stubs and to achieve a better image quality, the samples were coated with gold using an Emitech K500X manual sputter coater. The coated stubs were subsequently imaged under an Hitachi S-3600N Scanning Electron Microscope, with a working distance of $15 \mathrm{~mm}$ and voltage of $15 \mathrm{Kv}$. The relative change in diatom dissolution state was then assessed for the dominant taxa in each sample using the dissolution stage classification of Ryves, (1994) ${ }^{[21]}$ and the Diatom Dissolution index (DDI), ${ }^{[10,22]}$ Equation 1.

$D D I=\frac{\sum_{S=1}^{S=4} n s \cdot(S-1)}{N \cdot(\operatorname{Smax}-1)}$

Where $\mathrm{n}$ is the number of valves and $\mathrm{S}$ represents the stage of valve dissolution, $\mathrm{N}$ is the total number of classified valves. $S_{\max }$ is the highest stage that valves in the assemblage could reach if dissolution progressed to its end point; $S_{\max }$ thus varies between 2 and $4,{ }^{[10]}$ and here was 3 in all cases (see Table 2). The DDI enables the user to estimate the proportion of valves in a sample assemblage that are at the most dissolved state possible ${ }^{[10]}$ resulting in a 
numerical value for sample dissolution, with 0 indicating perfect preservation and 1 indicating the maximum dissolution possible for that species or assemblage if all species are included in the dissolution assessment ${ }^{[10]}$. Within each sample an area containing at least 100 valves of the dominant species was imaged (between 500 and 600x magnification), two additional images at the same magnification were subsequently taken to verify the initial DDI count. Although only the most important species (by relative abundance) were assessed for dissolution (Table 2), the DDI based on dominant taxa is a good estimate of assemblage DDI, which is a weighted mean of individual species DDIs. Similarly, while all biogenic silica contributes to sample $\delta^{18} \mathrm{O}$, in these samples the dominant taxa account for most of the biogenic silica (by biovolume). Dissolution stages for the dominant taxa (Table 2) were initially established by comparison to dissolution sequences published for the same genus and/or morphology ${ }^{[22]}$ and refined for each dominant taxon by identification of repeatable and distinct patterns in the valves under SEM/LM.

\begin{tabular}{ll} 
Stage $\mathbf{1}$ \\
\hline $\begin{array}{ll}\text { Coscinodiscus } \\
\text { spp. }\end{array}$ & $\begin{array}{l}\text { Girdle completely intact. Almost all } \\
\text { areolae have vela intact. Almost all } \\
\text { cellular mantle areolae have vela } \\
\text { intact. }\end{array}$
\end{tabular}

Gomphocymbella spp.

Aulacoseira skvortzowii

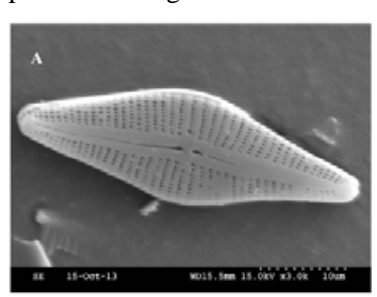

Mantle completely intact. Areole not enlarged, vela present on some species. No obvious signs of dissolution.

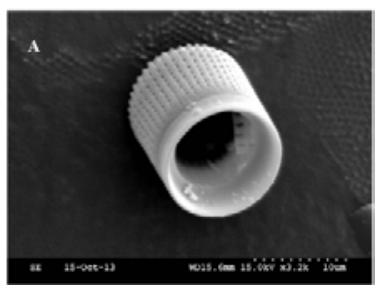

Stage 2 Most central areolae have lost vela and become enlarged. Some cellular mantle areole vela have been lost. Girdle almost completely intact.

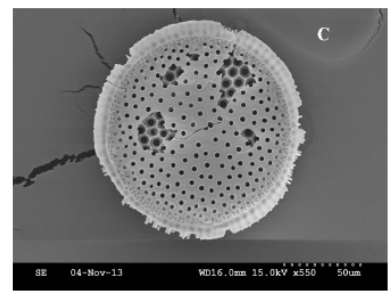

Puncta enlarged, with dissolution beginning at ends of frustule. Hypotheca and epitheca may separate, although not in this image.

Stage 3

Almost all areolae vela are lost, including all cellular mantle areolae vela. Girdle beginning to break down as areolae begin to coalesce.

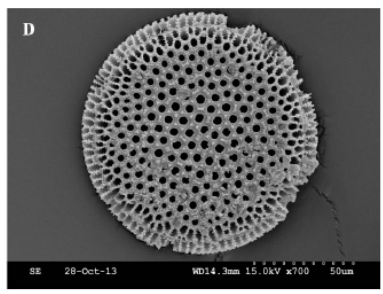

Epitheca and hypotheca typically separated, with only the costae remaining. Commonly seen as ‘skeleton' type remains.
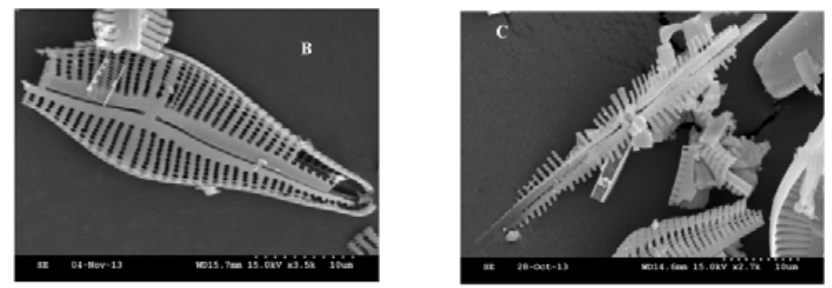

Areolae beginning to enlarge and coalesce. No vela present. Holes may become apparent as the areole begin to coalesce more.

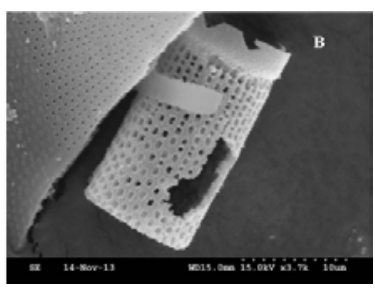

Breakdown of frustule as areole coalesce more completely. Frustule commonly in multiple parts.

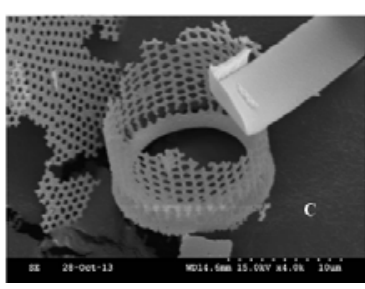


Stephanodiscus

formosus var

minor

Stephanodiscus grandis
Mantle intact with almost all marginal spines. Areolae remain separate and not overly enlarged.

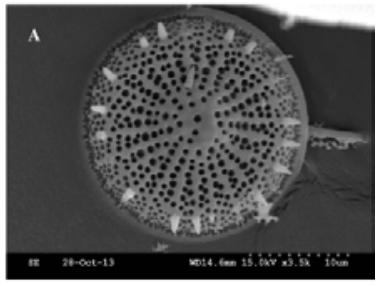

Mantle mostly intact, girdle still present.
Partial loss of the mantle and spines. Areolae beginning to enlarge and even coalesce.

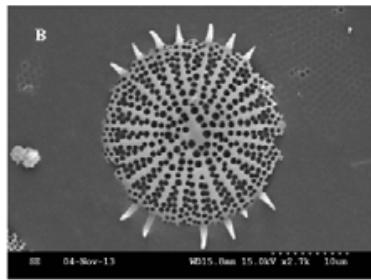

Margin irregular - girdle may be mostly removed. Areolae enlarged

and can coalesce.

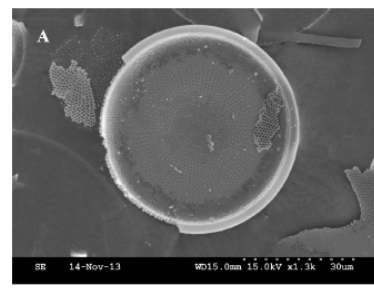

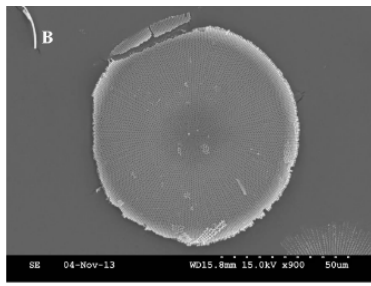

Complete loss of mantle and marginal spines. Areolae enlarged with many coalescing

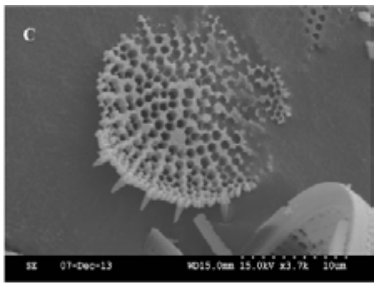

Margin dissolved, with breakage towards centre. Areolae enlarged, coalescing and breaking frustule.

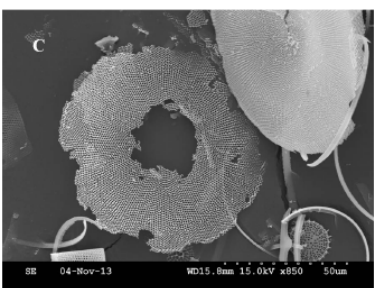

Table 2: SEM images of diatom dissolution stages for 5 of the prominent taxa recorded in the samples. Frustule degradation associated with dissolution can be clearly identified.

After dissolution, $\delta^{18} \mathrm{O}_{\text {diatom }}$ was determined using a Step Wise Fluorination (SWF) technique. $^{[18]}$ The initial SWF stages remove loosely bonded water (dehydration) and hydroxyl using a bromine pentafluoride $\left(\mathrm{BrF}_{5}\right)$ reagent. The next stage involves a full reaction at $450^{\circ} \mathrm{C}$ for 12 hours with an excess of reagent, causing the dissociation of the silica into $\mathrm{O}_{2}$ and $\mathrm{Si}$ (as $\mathrm{SiF}_{4}$ ). $\mathrm{O}_{2}$ is then liberated and converted to $\mathrm{CO}_{2}$ by exposure to graphite, whilst other products of the reaction $\left(\mathrm{SiF}_{4}, \mathrm{BrF}_{3}\right)$ are trapped using liquid nitrogen and either analysed, e.g. $\mathrm{Si}$, or disposed of. ${ }^{[18]}$ The resultant $\mathrm{CO}_{2}$ gas was then analysed for $\delta^{18} \mathrm{O}$ using a Thermo MAT 253 dual inlet isotope ratio mass spectrometer at the Stable Isotope Facility, British Geological Survey. Sample gas was calibrated against the BFC standard material which was in turn corrected to NBS28, $\delta^{18} \mathrm{O}_{\text {diatom }}$ is reported on the VSMOW scale. The DDI and $\delta^{18} \mathrm{O}$ data are given in Table 3 and Figure 2. A $2 \sigma$ error for the experiment was calculated based upon the mean standard deviation of duplicate analysis undertaken on all samples (including those pre-dissolution, in DI water for 48 days and those dissolved at $20{ }^{\circ} \mathrm{C}$ and 4 ${ }^{\circ} \mathrm{C}$ for 48 days) and was calculated at $0.46 \%$, very similar to the $2 \sigma$ error for repeat analysis of the BFC standard (from all experiments), 0.48\%.

\section{Results}

Dissolution 
Diatom dissolution was compared before $\left(\mathrm{t}=0\right.$ ) and after the experiments (48 days at $4^{\circ} \mathrm{C}$ and $20^{\circ} \mathrm{C}$ ) using the Diatom Dissolution Index as defined by Ryves et al., (2009) ${ }^{[22]}$ (Figure 1). Table 2 shows the typical stages of dissolution for major taxa. ${ }^{[22]}$ All diatom samples had a pre-dissolution DDI of 0.1-0.3, while DDI for all samples after 48 days (at both $20^{\circ} \mathrm{C}$ and $4^{\circ} \mathrm{C}$ ) ranged between 0.1 and 0.7 (Figure 1). For all samples, apart from the Miocene aged BFC, DDI was most extensive after 48 days in the $5 \% \mathrm{Na}_{2} \mathrm{CO}_{3}$ solution, and in the samples dissolved at $20^{\circ} \mathrm{C}$ (compared to those at $4^{\circ} \mathrm{C}$ ), similar to results of Demarest et al., (2009). ${ }^{[9]}$

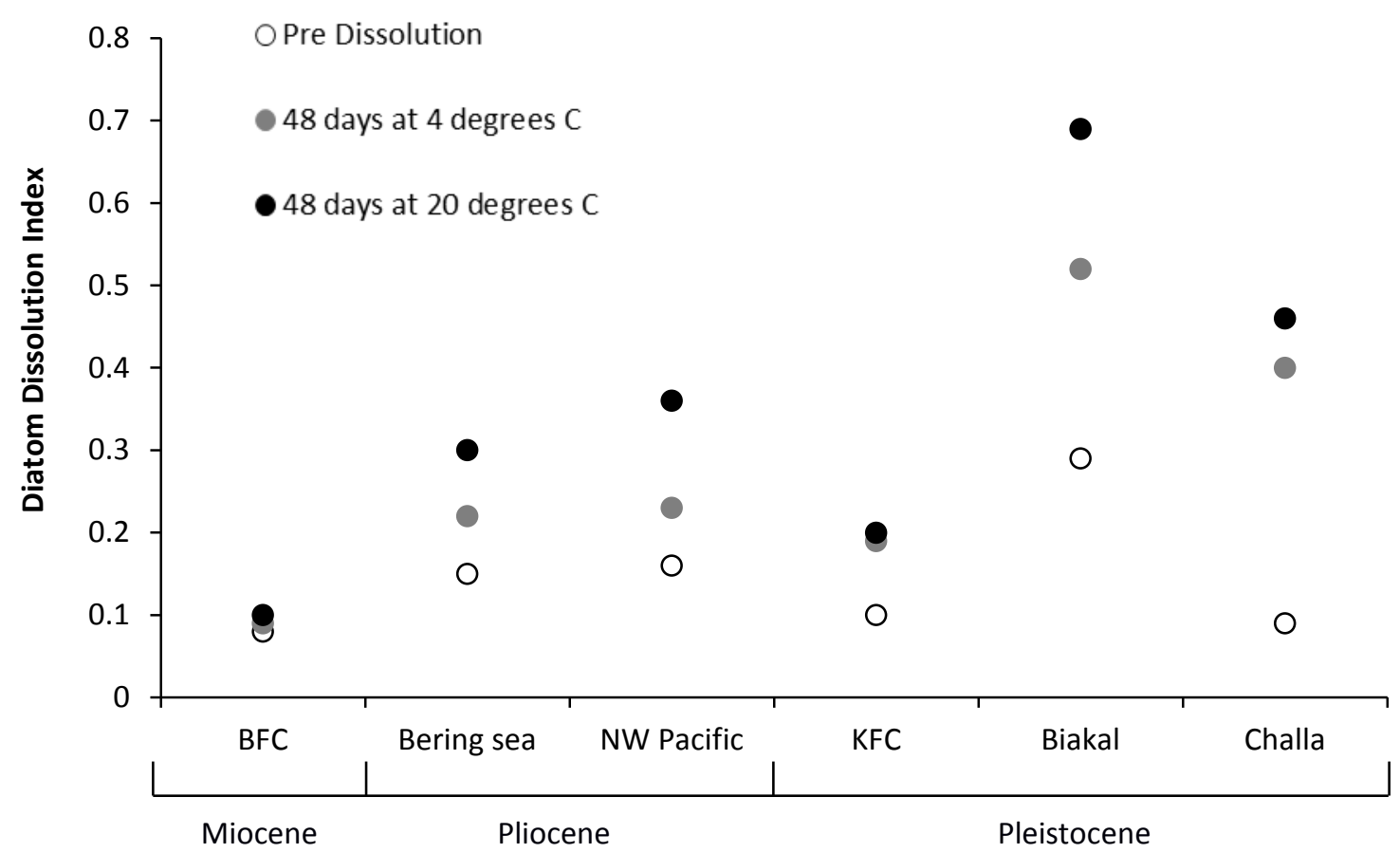

Figure 1: Diatom Dissolution Index for all samples (in descending age order) under the three different dissolution experiments. Open circles show the DDI pre-dissolution, grey circles after 48 days dissolution at $4^{\circ} \mathrm{C}$ and black circles after 48 days at $20^{\circ} \mathrm{C}$.

\section{Isotope composition}

The $\delta^{18} \mathrm{O}_{\text {diatom }}$ composition of the 6 diatom samples was analysed pre-dissolution, after dissolution for 48 days (at both $20^{\circ} \mathrm{C}$ and $4^{\circ} \mathrm{C}, \mathrm{pH}$ c. 11 ), and (for comparison) three of the samples (BFC, North West Pacific and Bering Sea) after 48 days in only deionised water. Pre-dissolution $\delta^{18} \mathrm{O}_{\text {diatom }}$ were between +26.92 and $+42.79 \%$ (Figure 2). For the three samples left for 48 days in DI water, we observed little dissolution under SEM. Change in $\delta^{18}$ Odiatom from pre-dissolution values was within analytical error $(0.46 \%)$ for two of the 
samples (BFC, $-0.09 \%$ and Bering Sea, $-0.38 \%$ ) but was outside this for the North West Pacific sample $(-0.99 \%)$.

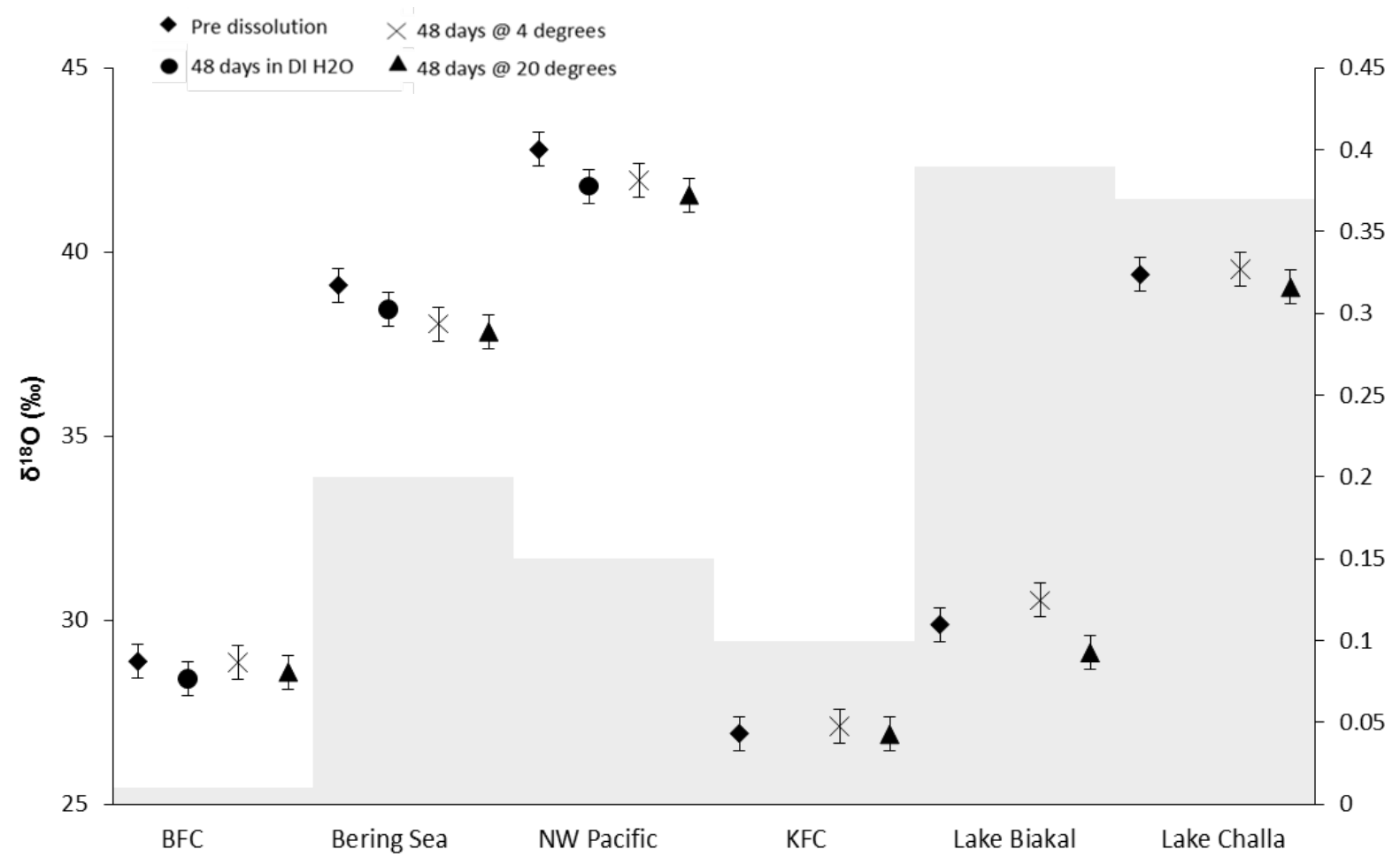

Figure 2: Change in $\delta^{18} \mathrm{O}$ between pre-dissolution isotope values (diamonds) and the two stages of dissolution, 48 days dissolution at $4^{\circ} \mathrm{C}$ (crosses) and 48 days at $20^{\circ} \mathrm{C}$ (triangles). Control experiment (48 days in DI water) shown with black circles, error bars denote the analytical error (0.46\%). Change in DDI (grey bars) between pre dissolution values and values after 48 days dissolution at $20^{\circ} \mathrm{C}$.

\begin{tabular}{lcccccc} 
& $\begin{array}{l}\delta^{18} \mathrm{O} \text { pre- } \\
\text { dissolution } \\
(\%)\end{array}$ & $\begin{array}{l}\delta^{18} \mathrm{O} \text { after } 48 \\
\text { days at } 4^{\circ} \mathrm{C} \\
(\%)\end{array}$ & $\begin{array}{l}\delta^{18} \mathrm{O} \text { after } 48 \\
\text { days at } 20^{\circ} \mathrm{C} \\
(\%)\end{array}$ & $\begin{array}{l}\text { DDI pre- } \\
\text { dissolution }\end{array}$ & $\begin{array}{l}\text { DDI after 48 } \\
\text { days at } 4^{\circ} \mathrm{C}\end{array}$ & $\begin{array}{l}\text { DDI after 48 } \\
\text { days at } 20^{\circ} \mathrm{C}\end{array}$ \\
\hline BFC & 28.88 & 28.86 & 28.59 & 0.08 & 0.09 & 0.10 \\
NW Pacific & 42.79 & $\mathbf{4 1 . 9 5}$ & $\mathbf{4 1 . 5 5}$ & 0.15 & 0.22 & 0.30 \\
Bering Sea & 39.10 & $\mathbf{3 8 . 0 5}$ & $\mathbf{3 7 . 8 4}$ & 0.16 & 0.23 & 0.36 \\
KFC & 26.92 & 27.11 & 26.90 & 0.10 & 0.19 & 0.20 \\
Lake Baikal & 29.88 & $\mathbf{3 0 . 5 4}$ & $\mathbf{2 9 . 1 2}$ & 0.29 & 0.52 & 0.69 \\
Lake Challa & 39.39 & 39.54 & 39.04 & 0.09 & 0.40 & 0.46 \\
\hline
\end{tabular}

Table 3: $\delta^{18} \mathrm{O}$ and Diatom Dissolution Index data for all samples pre-dissolution, after 48 days at $4^{\circ} \mathrm{C}$ and after 48 days at $20^{\circ} \mathrm{C}$. Samples with a $\delta^{18} \mathrm{O}$ change outside of error $(0.46 \%$ o) are highlighted in bold.

Of the six samples left to dissolve for 48 days at $4^{\circ} \mathrm{C}$, only the Bering Sea sample (change of $-1.05 \%$ ) and the North West Pacific sample ( $-0.84 \%$ change) show a reduction in isotope 
value from the pre-dissolved material outside the sample analytical $(2 \sigma)$ error (average change in all samples $=-0.15 \%$ ). The Lake Baikal sample shows a slight (but significant) increase $\delta^{18} \mathrm{O}_{\text {diatom }}(+0.66 \%)$ at this temperature. All samples from the 48 days at $20^{\circ} \mathrm{C}$

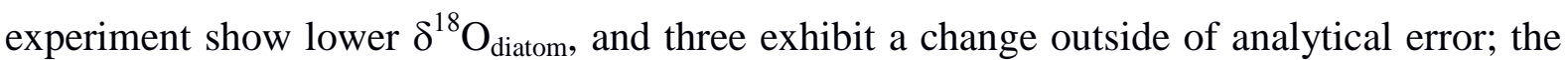
Bering Sea (-1.26\%), NW Pacific (-1.23\%o) and Lake Baikal (-0.76\%o), with average change in all samples of $-0.65 \%$ (Figure 2 ).

\section{Discussion}

\section{Diatom dissolution and oxygen isotope fractionation}

Isotope change during these experiments is potentially related to two different isotope fractionation processes. Firstly, the slow equilibrium oxygen isotope exchange between diatom silica and the surrounding water. This process occurs on the molecular level and takes a lot of time (or energy) to cause significant isotope exchange; it is therefore unlikely that this process could cause large changes in $\delta^{18} \mathrm{O}_{\text {diatom }}$ over the short time period of these experiments. However, the second form of isotope fractionation is a kinetic process driven by the preferential dissolution of sections of the diatom frustule. This process occurs far more rapidly and thus therefore more likely to cause the isotope shifts observed here.

Overall, the diatom dissolution experiments reported here show that, in general, the oldest diatoms are least affected by further experimental dissolution (Figure 1), as expected as biogenic silica ages geologically and becomes more crystalline. ${ }^{[5]}$ However KFC (Pleistocene) is an exception, with lower levels of dissolution (DDI change $=0.1$ ), although this likely still represents a substantial loss of diatoms (perhaps $~ 30 \%$ disappear as DDI rises from 0.1 to 0.2 ; see Ryves et al. $2006^{[10]}$ ). This might speculatively be related to clay contamination within the sample. Whilst differences in the extent of diatom dissolution occurred among the six samples corresponding to the sample age, changes in $\delta^{18} \mathrm{O}_{\text {diatom }}$ appear de-coupled from the amount of dissolution (Figure 2 and Table 3). The change in DDI between assemblages prior to dissolution and after dissolution at $20^{\circ} \mathrm{C}$ ranges from 0.01 (BFC) to 0.39 (Lake Baikal), but this variation does not appear related to the $\delta^{18} \mathrm{O}_{\text {diatom }}$ (linear regression, $n=6, r^{2}=0.04$ ). This dissimilarity between the change in diatom dissolution and the difference in isotope value indicates that there is no overarching relationship between

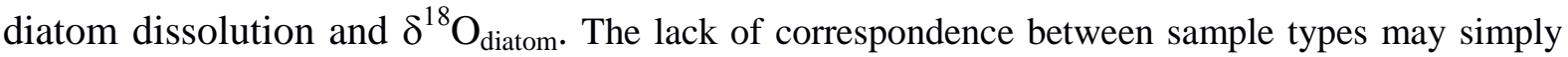
reflect differences in the source material, highlighting the potential roles of assemblage 
composition, sample age, the extent of prior diagenetic processing, taphonomic history as well as preferential dissolution in controlling how $\delta^{18} \mathrm{O}_{\text {diatom }}$ changes during dissolution. Whilst the amount of dissolution is not directly related to the change in $\delta^{18} \mathrm{O}_{\text {diatom }}$ and even though samples may dissolve in different ways due to their initial assemblage makeup our results demonstrate that dissolution almost always (one exception) causes a small negative shift in $\delta^{18} \mathrm{O}_{\text {diatom; }}$; different from the large positive shifts in $\delta^{18} \mathrm{O}_{\text {diatom }}$ described in cultured diatoms. ${ }^{[9]}$ This is potentially because our experiments are an assessment of secondary (within sediment), rather than the primary (within water column) dissolution mimicked in Moschen et al., (2006). ${ }^{[9]}$

\section{Significance for palaeoenvironmental reconstruction}

The results of this study show that a change in $\delta^{18} \mathrm{O}_{\text {diatom }}$ occurs in fossil samples with further induced diatom dissolution (Table 3). It should be noted that most diatoms will previously have undergone dissolution either during their settling through the water column ${ }^{[9]}$ or at the sediment surface-water interface (or both; ${ }^{[10]}$ ) and that the impacts of this earlier dissolution cannot be tested here. At $20^{\circ} \mathrm{C}$, the fractionation related to simulated post-burial dissolution occurs outside of measurement error $(-1.24 \%$, $-1.26 \%$ and $-0.76 \%$ o for three of the six samples (NW Pacific, Bering Sea and Lake Baikal respectively, Table 3). However, such temperatures are unlikely to be representative of conditions within the sediments of many deep waters or high altitude/ latitude lakes, where carbonate deposits are rare. Therefore the colder, $4^{\circ} \mathrm{C}$ experiment is likely more representative of the majority of natural lake and ocean sediment conditions. ${ }^{[8]}$ This experiment showed smaller, but still significant (outside of $2 \sigma$ error), changes in $\delta^{18} \mathrm{O}_{\text {diatom }}(-1.05 \%$, $-0.84 \%$ and $+0.66 \%$ o) in the Bering Sea, NW Pacific and Lake Baikal samples respectively (Table 3). In our six samples dissolved at $4^{\circ} \mathrm{C}$, we observe a maximum isotope change related to dissolution of $-0.59 \%$ (Bering Sea) beyond the analytical error (0.46\%).

When compared with modern palaeoclimate reconstructions using $\delta^{18} \mathrm{O}_{\text {diatom, even extreme }}$ dissolution of the sedimentary diatom material resulting in a $<0.59 \%$ o $\delta^{18} \mathrm{O}_{\text {diatom }}$ shift would not always influence palaeoclimate interpretation. Several examples include; Barker et al., (2001) ${ }^{[23]}$ interpret isotope shifts of $<18 \%$ as changes in Holocene moisture balance from two Alpine lakes on Mt Kenya; Mackay et al., (2013) ${ }^{[4]}$ describe shifts in $\delta^{18} \mathrm{O}_{\text {diatom }}$ of up to 3\% in the Last Interglacial sequence from Lake Baikal, indicative of changing strength of the 
Siberian High on regional hydrology. Other examples include Dean et al., (2013) ${ }^{[24]}$ where they show changes of $<20 \%$ from Nar Gölü in central Turkey related to lake freshening after intense snow melt; Shemesh et al., $(2001)^{[25]}$ describe changes of $<3.5 \%$ from a lake in Swedish Lapland and interpret these as an indicator of changing air mass dominance through the Holocene; Leng et al., $(2001)^{[26]}$ describe shifts in $\delta^{18} \mathrm{O}_{\text {diatom }}$ of up to $16 \%$ in Lake Pinarbasi (Turkey), which reflect changes in lake water dilution during periods of diatom growth. Finally,Shemesh et al., (1995) ${ }^{[27]}$ found changes of up to 5\% between diatom samples from the Holocene and the last glacial maximum in the Southern Ocean.

Whilst all of these studies successfully use $\delta^{18} \mathrm{O}_{\text {diatom }}$ as a palaeoclimate proxy, none attempt to reconstruct palaeo-water temperatures based on relatively small changes in $\delta^{18} \mathrm{O}_{\text {diatom, }}$, where our results may be of greater consequence. Temperature related fractionation of $\delta^{18} \mathrm{O}_{\text {diatom }}$ has been calculated at between -0.2 to $-0.5 \%$ o $/{ }^{\circ} \mathrm{C} .{ }^{[1,28,29]}$ Taking the lower estimate of $-0.2 \% /{ }^{\circ} \mathrm{C}$ our dissolution-biased fractionation could be misinterpreted as a change in water temperature of $\sim 3^{\circ} \mathrm{C}$. We therefore recommend that if $\delta^{18} \mathrm{O}_{\text {diatom }}$ is to be used for palaeoclimate reconstruction, then dissolution states of diatom frustules should be considered. In cases where extreme diatom dissolution is identified, palaeoclimate reconstructions that identify changes of $\sim 1 \%$ should be carefully evaluated and perhaps treated with some circumspection.

\section{Conclusions}

The potential for diatom dissolution within sediments appears strongly related to the age of diatom samples, with older samples (Miocene), being more resistant to further dissolution, even under highly alkaline conditions and high temperatures. The experiment undertaken at $4^{\circ} \mathrm{C}$ identifies reductions in diatom oxygen isotope value $(<1.05 \%,-0.59 \%$ o beyond error), especially in younger samples. Palaeoclimate reconstructions using $\delta^{18} \mathrm{O}_{\text {diatom }}$ should therefore consider post burial dissolution at sites where palaeoclimate reconstructions are based on fluctuations in diatom $\delta^{18} \mathrm{O}$ lower than $1 \%$, especially if palaeo-temperature reconstruction is being considered. At such sites, the use of the DDI may help to constrain the extent of postmortem diatom dissolution, and allow for a considered decision about the appropriateness of the assemblage for palaeoclimate reconstruction. 


\section{Acknowledgements}

The original data from this study was obtained by Michael Hems as part of his MGeol dissertation at Leicester University and was also support by NERC Isotope Geosciences Facilities Steering Committee award IP-1533-0515.

\section{References}

[1] M. J. Leng, P. A. Barker.A review of the oxygen isotope composition of lacustrine diatom silica for palaeoclimate reconstruction. Earth-Science Reviews2006, 75, 5.

[2] G. E. A. Swann, M. J. Leng.. A review of diatom $\delta^{18} \mathrm{O}$ in palaeoceanography. Quaternary Science Reviews 2009, 28, 384.

[3] J. Pike, G. E. A. Swann, M. J. Leng, A. M. Snelling. Glacial discharge along the west Antarctic Peninsula during the Holocene. Nature Geoscience, 2013, 7, 199.

[4] A. W. Mackay, G. E. A. Swann, N. Fagel, S. Fietz, M. J. Leng, D. Morley, P. Rioual, P. Tarasov. Hydrological instability during the Last Interglacial in central Asia: a new diatom oxygen isotope record from Lake Baikal. Quaternary Science Reviews, 2013, 66, 45.

[5] J. C. Lewin. The dissolution of silica from diatom walls. Geochimica et Cosmochimica Acta, 1961, 21, 182.

[6] J. P. Dodd, Z. D. Sharp, P. J. Fawcett, A. J. Brearley, F. M. McCubbin. Rapid postmortem maturation of diatom silica oxygen isotope values. Geochemistry, Geophysics, Geosystems, 2012, 13(9), Q09014.

[7] M. S. Demarest, M. A. Brzezinski, C. P. Beucher. Fractionation of silicon isotopes during biogenic silica dissolution. Geochimica et Cosmochimica Acta, 2009, 73, 5572.

[8] D. B. Ryves, D. H. Jewson, M. Sturm, R. W. Battarbee, R. J. Flower, A. W. Mackay, N. G. Granin. Quantitative and qualitative relationships between planktonic diatom communities 
and diatom assemblages in sedimenting material and surface sediments in Lake Baikal, Siberia. Limnology and Oceanography, 2003, 48, 1183.

[9] R. Moschen, A. Lücke, J. Parplies, U. Radtke, G. H. Schleser. Transfer and early diagenesis of biogenic silica oxygen isotope signals during settling and sedimentation of diatoms in a temperate freshwater lake (Lake Holzmaar, Germany). Geochimica et Cosmochimica Acta, 2006, 70, 4367.

[10] D. B. Ryves, R. W. Battarbee, S. Juggins, S. C. Fritz, N. J. Anderson. Physical and chemical predictors of diatom dissolution in freshwater and saline lake sediments in North America and West Greenland. Limnology and Oceanography, 2006, 51, 1355.

[11] P. A. Barker. Differential diatom dissolution in Late Quaternary sediments from Lake Manyara, Tanzania: an experimental approach. Journal of Paleolimnology, 1992, 7, 235.

[12] P. A. Barker, J.-Ch. Fontes, F. Gasse, J.-Cl. Druart. Experimental dissolution of diatom silica in concentrated salt solutions and implications for palaeoenvironmental reconstruction. Limnology and Oceanography, 1994, 39, 99.

[13] D. B. Ryves, S. Juggins, S. C. Fritz, R. W. Battarbee. Experimental diatom dissolution and the quantification of microfossil preservation in sediments. Palaeogeography, Palaeoclimatology, Palaeoecology, 2001, 172, 99.

[14] R. J. Flower, D. B. Ryves. Diatom preservation: differential preservation of sedimentary diatoms in two saline lakes. Acta Botanica Croatica, 2009, 68, 381.

[15] D. J. Conley, C. L. Schelske. Biogenic Silica. In: J. P. Smol, H. J. B. Birks, W. M. Last (eds) Tracking environmental change using lake sediments: Volume 3. Kluwer Academic Publishers, Dordrecht, 2001, 281.

[16] N. Mikkelsen. Experimental dissolution of Pliocene diatoms. Nova Hedwigia, 1980, 33, 893. 
[17] M. J. Leng, G. E. A. Swann, M. J. Hodson, J. J. Tyler, S. V. Patwardhan, H. J. Sloane. The Potential use of Silicon Isotope Composition of Biogenic Silica as a Proxy for Environmental Change. Silicon, 2009, 1, 65-77.

[18] M. J. Leng, H. J. Sloane,. Combined oxygen and silicon isotope analysis of biogenic silica. Journal of Quaternary Science, 2008, 23, 313.

[19] M. Schmidt, R. Botz, D. Rickert, G. Bohrmann, S. R. Hall, S. Mann. Oxygen isotopes of marine diatoms and relations to opal-A maturation. Geochimica et Cosmochimica Acta, 2001, 65, 201-211.

[20] K. D. Bidle, F. Azam. Accelerated dissolution of diatom silica by marine bacterial assemblages. Nature, 1999, 397, 508.

[21] D. B. Ryves. Diatom dissolution in saline lake sediments: an experimental study in the Great Plains of North America. 1994, Ph.D. dissertation, University College London.

[22] D. B. Ryves, R. W. Battarbee, S. C. Fritz. The dilemma of disappearing diatoms: Incorporating diatom dissolution data into palaeoenvironmental modelling and reconstruction. Quaternary Science Reviews, 2009, 28, 120.

[23] P. A. Barker, F. A. Street-Perrott, M. J. Leng, P. B. Greenwood, D. L. Swain, R. A. Perrott, J. Telford, K. J. Ficken. A 14 ka oxygen isotope record from diatom silica in two alpine tarns on Mt. Kenya. Science, 2001, 292, 2307.

[24] J. R. Dean, M. D. Jones, M. J. Leng, H. J. Sloane, C. N. Roberts, J. Woodbridge, G. E. A. Swann, S. E. Metcalfe, W. J. Eastwood, H. Yiğitbaşığlu. Palaeo-seasonality of the last two millennia reconstructed from the oxygen isotope composition of carbonates and diatom silica from Nar Gölü, central Turkey. Quaternary Science Reviews, 2013, 66, 35-44.

[25] A. Shemesh, G. Rosqvist, M. Rietti-Shati, L. Rubensdotter, C. Bigler, R. Yam, W. Karlen, . Holocene climatic change in Swedish Lapland inferred from an oxygen-isotope record of lacustrine biogenic silica. Holocene, 2001, 11, 447- 454. 
[26] M.J. Leng, P. Barker, P. Greenwood, N. Roberts, J. M. Reed. Oxygen isotope analysis of diatom silica and authigenic calcite from Lake Pinarbasi, Turkey. Journal of Paleolimnology, 2001, 25, 343-349.

[27] A. Shemesh, L. H. Burckle. J. D. Hays. Late Pleistocene oxygen isotope records of biogenic silica from the Atlantic sector of the Southern Ocean. Palaeocenography, 1995, 10(2), 179.

[28] M. E. Brandriss, J. R. O’Neil, M. B. Edlund, E. F. StoermerOxygen isotope fractionation between diatomaceous silica and water. Geochimica et Cosmochimica Acta, 1998, 62, 1119.

[29] R. Moschen, A. Lucke, G. H. Schleser. Sensitivity of biogenic silica oxygen isotopes to changes in surface water temperature and palaeoclimatology. Geophysical Research Letters,2005, 32, doi:10.1029/2004GL022167.

[30] B. Chapligin, M. J. Leng, E. Webb, A. Alexandre, J. P. Dodd, A. Ijiri, A. Lücke, A. Shemesh, A. Abelmann, U. Herzschuh, F. J. Longstaffe, H. Meyer, R. Moschen, Y. Okazaki, N. H. Rees, Z. D. Sharp, H. J. Sloane, C. Sonzogni, G. E. A. Swann, F. Sylvestre, J. J. Tyler, R. Yam. Inter-laboratory comparison of oxygen isotope compositions from biogenic silica. Geochimica et Cosmochimica Acta, 2011, 75, 7242.

[31] G. E. A. Swann, M. A. Maslin, M. J. Leng, H. J. Sloane, G. H. Haug. Diatom $\delta^{18} O$ evidence for the development of the modern halocline system in the subarctic northwest Pacific at the onset of major Northern Hemisphere glaciation. Paleoceanography, 2006, 21, PA1009.

[32] J. J. Tyler, M. J. Leng, H. J. Sloane. The effects of organic removal treatment on the integrity of $\delta^{18} \mathrm{O}$ measurements from biogenic silica. Journal of Paleolimnology, 2006, 37, 491.

[33] P. Rioual, A. W. Mackay. A diatom record of centennial resolution for the Kazantsevo Interglacial stage in Lake Baikal (Siberia). Global and Planetary Change, 2005, 46, 199. 
[34] P. A. Barker, E. R. Hurrell, M. J. Leng, B. Plessen, C. Wolff, D. J. Conley, E. Keppens, I. Milne, B. F. Cumming, K. R. Laird, C. P. Kendrick, P. M. Wynn, D. Verschuren. Carbon cycling within an East African lake revealed by the carbon isotope composition of diatom silica: a 25-ka record from Lake Challa, Mt. Kilimanjaro. Quaternary Science Reviews, 2013, $66,55$. 